\title{
Soil Structural Analysis of Laterite Properties used as a Road Construction Material, Abuja as a Case Study
}

\author{
${ }^{1}$ Onyeka, F. C., ${ }^{2}$ Osegbowa Douglas \\ ${ }^{1,2}$ Department of Civil Engineering, Edo University, Iyamho, Nigeria
}

\begin{abstract}
This study presents the structural analysis of soil used as a road construction material, to assess the required properties for improved stabilization. This is done by determining the relationship between the force and penetration cylinder plunger of a standard cross-sectional area which is made to penetrate at a specified rate. The compaction of soil sample gotten from three Abuja laterite deposits was analyzed by subjecting it to moisture content test, atterberg limit test, dry density test, specific gravity test, Californian bearing ratio (CBR), and compaction tests using modified proctor equipment. Their natural moisture content, plasticity index, maximum dry density (MDD), Optimum Moisture Content (OMC), Specific gravity and CBR lies between 5.7-7.6\%, 8.5-10.3, 1810$2210 \mathrm{Kg} / \mathrm{M}^{3}, \quad \mathbf{1 6} .2-18.4 \%, \quad 2.02-2.49$ and $33.1-50.8 \%$ respectively. The results showed that Muko soil meets the required specification and can be recommended as most suitable a sub-base course used for road construction material when compared with that of Jikwoyi and Apiwe laterite soil material.
\end{abstract}

Keywords: Laterites, Soil structural analysis and tests, Road construction material and Modified proctor equipment.

\section{INTRODUCTION}

Road networks are very important infrastructure to every country's economy as it enables persons, goods and services to be moved from one destination to another. As a result, the Nigerian Government has shown great interest in improving the road infrastructures in Nigeria, due to their economic importance according to Olanyiyan et al. (2019). It is generally known that soils such as lateritic soil are usually used as sub-base and base materials in road construction. The term "lateritic soil" has been described by different researchers in relation to its chemical compositions, physical properties and mode of formation etc. Laterites have been described as soils that are mainly made up of iron and aluminum as revealed in Arinze and Ibe (2015) and they are commonly formed in locations with tropical conditions, revealed in Tijaniet al. (2017). They are formed from the weathering of rocks which can be igneous, sedimentary and metamorphic rocks under necessary condition (Rahardjo et al., 2004).
Aginamet al. (2014) revealed that the weathering of rocks for the formation of lateritic soils involves the progressive chemical changes of the main minerals which result in the discharge of iron and aluminum. Enaworu et al. (2017) showed further that lateritic soils also contain high amount of kaolinite and quartz with no silicates properties. Ola (1978) described lateritic soils from an Engineering view without laboratory testing as the results from tropical weathering with red, reddish brown or dark color.

Prasad and Parthasarathy (2016) described laterization or laterite genesis as the process of alteration involve in the formation of laterites from existing rocks.Aginamet al. (2015) further described laterization as a slow process which depends on the nature and degree of chemical weathering. According to Arinze and Ibe (2015) laterites can be on mafic (gabbro, basalt) including ultra mafic rocks (dunite etc) which are formed from rocks which does not contain quartz, but with smaller quantities of silica and greater amount of iron. While laterites on acidic rocks are formed, with the reversed process of laterites on mafic formation, examples are granites, clays, shales etc. Lateritic soils are used as construction material for the construction of roads, foundations, landfill, houses etc. (Enaworu et al., 2017; Ezeet al., 2017; Ehujuo et al., 2017).

Akintorinwa et al. (2012) stated that lateritic soils are used in road construction in Nigeria just like in other developing countries of the world. Layade and Ogunkoya (2018) revealed that lateritic soils are used as base materials in road construction due to their binding properties and ease of using them to attain desired results. Lateritic soils Geotechnical properties depends on the kind of parent rocks and the extent of their weathering, atmospheric condition and geological formation etc. (Enaworu et al., 2017), observed the need of carrying out a detailed investigation of the Geotechnical properties of lateritic soil- that such information aid lateritic soil user to determine if the intended lateritic soil meets the necessary requirements for the intended engineering application.

Abiola et al. (2018) established that the Geotechnical properties of lateritic soil can be enhanced/modified through stabilization before used for engineering purposes due to its silt content, liquid limit and plasticity index levels. Ogbuagu 
and Okeke (2019) asserted that the durability, stability, of roads depends vastly on the knowledge of the Geotechnical properties of the soil used in constructing them. The FMWH (1997) stipulated the following requirements: the percentage passing BS 200 sieve should not be greater than 35\%, for sub grade, sub-base and base material. Also the sub grade material should have $\mathrm{LL} \leq 50 \%$, and $\mathrm{PI} \leq 30 \%$, while for sub-base material, should have $\mathrm{LL} \leq 30 \%$ and $\mathrm{PI} \leq 12 \%$ respectively. The stipulation further stated that un soaked CBR for sub grade, sub-base, and base materials should be: $\leq 10 \%, \leq 30 \%$ and $\leq 80 \%$ respectively.

Osim (2006) revealed that soils in major locations in North Central zone of Nigeria were of good quality to be used as a base course during road construction except in a few areas like Abuja - Lokoja/Abuja - Keffi, Otukpa and Yelewa with classification: A-4, A-7-6 and A-6 respectively. His studies further revealed that majority of the soils in the zone were suitable as sub-grade material except in a few locations like: Lambata, Suleija, Abuja-Keffi, Nasara Loko, Otukpa, Minna where the soils did not meet the necessary requirements.

Amadi et al. (2015) investigated the suitability of lateritic soils in North Central Nigeria for road construction. They determined the Geotechnical properties, of the lateritic soil in accordance with British standards (BS). They found out that, the PL, MDD, and the CBR gave high results while the LL, PI and $\mathrm{OMC}$, gave lower results for the lateritic soils which were classified as A-3, A-2-4, and A-2-6 respectively. They concluded from their results that the lateritic soils were suitable for road construction.

Avwenagha et al. (2014) worked on the properties of lateritic soils. They determined the classification and compaction attributes of the lateritic soils they collected from eight (8) different locations in Delta state, Nigeria. They found out that the soil samples were A6, A3 and most especially A24 based on an AASTHO soil system of classification. Their study revealed that the soils were suitable as sub-grade material for road construction but with the need for stabilization for them to be fitted as sub-base and base material for the purpose of road construction.

Habeeb et al. (2012) researched on lateritic soil properties for road construction purpose. They collected the different soil samples they used for the research from borrow pit, in Oyo state, Nigeria. They carried out Atterberg limit, compaction, CBR, particle size distribution and specific gravity tests using the soil samples. Their results revealed that the subgrade samples were A-1-b, and A-2-4, while the base sample was A2-7 based on the AASHTO soil classification system. While the soil had unsoaked CBR values ranging between: $78 \%-$ $132 \%, \operatorname{MDD}\left(1.90 \mathrm{mg} / \mathrm{m}^{3}-2.19 \mathrm{mg} / \mathrm{m}^{3}\right), \mathrm{OMC}(5.4 \%-14.2 \%)$, and specific gravity (2.65-2.68). They concluded by rating the subgrade samples from being excellent to good, while a base sample from fair to poor.

Onyelowea and Agunwamba (2012) examined the properties of lateritic soil from Abia state, Nigeria. They collected the lateritic soil sample from a borrow pit in Umuahia North L.G.A, of the state. The conducted Atterberg limit, particle size distribution/sedimentation, and compaction test using the soil sample. Their investigation revealed the soil sample as A-2-7 based on the AASHTO soil classification system, while the MDD, OMC and CBR were $1.90 \mathrm{mg} / \mathrm{m}^{3}$, $14.76 \%$ and $26 \%$ respectively. They concluded that the soil was appropriate as subgrade material for road construction while stabilization would be needed for it to be used as subbase and road base material.

Literatures have revealed that soilsin same location, state or geopolitical zone cannot have the same Geotechnical properties - as such, it is very important to determine the Geotechnical properties of soils before their utilization for any engineering construction. Also one can rarely find any work on the structural analysis of soil used for road construction purpose. This study is aimed at carrying out structural analysis of lateritic soil obtained from Abuja, North Central zone, of Nigeria, used as material for road construction.

\section{MATERIALS AND METHODS}

Distributed soil sample were collected from Muko borrow pit, Jikwoyi borrow pit and Apiwe borrow pit, Abuja in Federal capital territory of Nigeria and each of the samples were labeled $\mathrm{X}, \mathrm{Y}$ and $\mathrm{Z}$ respectively. The following tests were carried out accordingly on each of the samples. This sample laterite soil samples were collected from the wall of the borrow pits and the depth at which they are collected were specified and recorded.

The other materials used in the project are modified proctor equipment which composes of the mould and its plate, rammer of $2.5 \mathrm{~kg}$ falling freely from a height of $450 \mathrm{~mm}$ in four (4) layers having a blow of 25 of which the maximum dry density is ranged and its corresponding optimum moisture content (OMC) also determined from the graph.

\subsection{Laboratory Test}

A laboratory test that was carried out in the curse of this project includes: The particle size distribution, the liquid limit test, the plastic limit test, compaction test using cement and the soils alone. The California Bearing Ratio (CBR) was also carried out. 
All the samples of the soils use in this project were first after the practical test classified using (AASHTO and FMWH) soil classification chart to determine if they need stabilization or not and what type of stabilization will help in improving the engineering properties of such soil sample.

\section{ANALYSIS OF RESULTS AND DISCUSSIONS}

From the results obtained from the various experiment carried out into the cause of this work, analysis and calculation were deduced as follows.

\subsection{Analysis of Test Result of X, Y and Z Sample}

The result of $\mathrm{X}, \mathrm{Y}$ and $\mathrm{Z}$ sample as presented in Table 1 to Table 5 shows that the Natural Moisture Content obtained from soil sample $\mathrm{X}, \mathrm{Y}, \mathrm{Z}$ is $5.7 \%, 7.6 \%$ and $7.6 \%$, Specific gravity of 2.40, 2.49 and 2.02. The Atterberg limit tests were recorded in line with work of Arinze and Ibe (2015). The value of Liquid limit of $26 \%, 26.5 \%$ and $28.2 \%$ at 25 blows was recorded while the Plastic limit of $16.6 \%, 17.7 \%$ and $17.9 \%$ on average of 25 blows. The Plasticity index calculated from $\mathrm{X}, \mathrm{Y}$ and $\mathrm{Z}$ samples were $9.4 \%, 8.5 \%$ and $10.35 \%$, while the Percentage passing 200 micron sieve of $43 \%, 37 \%$ and $37 \%$ respectively. The sieve analysis results are presented in the Figure1 to 3 while the results of Moisture content, C.B.R and Dry density is presented in the Figure 4 to 6.

The American Association of State Highway and Transportation Officials (AASHTO) classifications of soils show that sample $\mathrm{X}$ to Sample $\mathrm{Y}$ are A-4 soils with their group index lying between 0 and 1 . Sample $\mathrm{Z}$ is classified as A-5 with group index of 4 . This implies that samples $X$ and $Y$ are suitably adequate, whereas sample $\mathrm{Z}$ is fairly suitable adequate (FGN, 1997).

\begin{tabular}{|c|c|c|c|c|c|}
\hline \multirow[t]{2}{*}{ Sample } & \multirow{2}{*}{$\begin{array}{l}\text { Wt of } \\
\text { bottle }(\mathrm{g}) M_{1}\end{array}$} & \multirow{2}{*}{$\begin{array}{l}\text { Bottle } \\
+ \text { sample }(g) M_{2}\end{array}$} & \multirow{2}{*}{$\begin{array}{c}\text { Bottle }+ \text { sample }+\mathrm{H}_{2} \mathrm{O}(\mathrm{g}) \\
M_{3}\end{array}$} & \multirow{2}{*}{$\begin{array}{c}\text { bottle }+\mathrm{H}_{2} \mathrm{O}(\mathrm{g}) \\
M_{4}\end{array}$} & \multirow{2}{*}{$\begin{array}{l}\text { Specific gravity } \\
\frac{M_{2}-M_{1}}{\left(M_{4}-M_{1}\right)-\left(M_{3}-M_{2}\right)} \\
\left(\mathrm{g} / \mathrm{cm}^{3}\right)\end{array}$} \\
\hline & & & & & \\
\hline $\mathbf{X}$ & 582.3 & 1321.4 & 1985.6 & 1554.2 & 2.40 \\
\hline Y & 582.3 & 1298.5 & 1895.9 & 1467.4 & 2.49 \\
\hline $\mathrm{Z}$ & 582.3 & 1245.6 & 1822.3 & 1487.9 & 2.02 \\
\hline
\end{tabular}

Average Specific Gravity $G_{S}=\frac{X+Y+Z}{3}=\frac{2.40+2.49+2.02}{3}=\frac{6.91}{3}=2.30$

\begin{tabular}{|l|l|l|l|l|l|l|l|}
\hline \multicolumn{2}{c}{ Table 2: Liquid and Plastic Limits for Sample X } \\
\hline \multicolumn{1}{|c|}{ Test Type } & Expression & \multicolumn{3}{c|}{ Liquid Limit } & \multicolumn{3}{c|}{ Plastic Limit } \\
\hline Number of Blows & & 11 & 20 & 26 & 40 & & \\
\hline Number of Container & & 5 & 38 & 14 & 9 & 23 & 24 \\
\hline Weight of soil + container & W2 & 41.3 & 38.6 & 37.5 & 36.1 & 35.7 & 35.8 \\
\hline Weight of dry soil container & W3 & 36.8 & 35.1 & 34.5 & 33.8 & 33.9 & 34.0 \\
\hline Weight of empty container & W1 & 23.0 & 23.0 & 23.0 & 23.0 & 23.0 & 23.0 \\
\hline Weight of moisture & W2-W3(a) & 4.50 & 3.50 & 3.0 & 2.30 & 1.80 & 1.8 \\
\hline Weight of dry soil & W3-W1(b) & 13.8 & 12.1 & 11.5 & 10.8 & 10.9 & 11.0 \\
\hline Moisture Content & 100*(a-b) & 32.7 & 29.3 & 26.1 & 21.7 & 16.8 & 16.4 \\
\hline
\end{tabular}

Therefore, the Liquid limit at blow $25=26 \%$; Plastic limit $=16.6 \%$; Plasticity index $=9.4$

Table 3: Liquid and Plastic Limits for Sample Y

\begin{tabular}{|l|l|l|l|l|l|l|l|}
\hline \multicolumn{1}{c}{ Test Type } & Expression & \multicolumn{3}{c|}{ Liquid Limit } & \multicolumn{3}{c|}{ Plastic Limit } \\
\hline Number of Blows & & 10 & 19 & 27 & 35 & & \\
\hline Number of Container & & 7 & 25 & 11 & 42 & 34 & 15 \\
\hline Weight of soil + container & W2 & 39.8 & 36.7 & 37.7 & 36.2 & 35.4 & 35.2 \\
\hline Weight of dry soil container & W3 & 35.4 & 33.5 & 34.6 & 33.8 & 33.6 & 33.4 \\
\hline Weight of empty container & W1 & 23.0 & 23.0 & 23.0 & 23.0 & 23.0 & 23.0 \\
\hline Weight of moisture & W2-W3(a) & 4.4 & 3.2 & 3.1 & 2.4 & 1.80 & 1.80 \\
\hline Weight of dry soil & W3-W1(b) & 12.4 & 10.5 & 11.6 & 10.8 & 10.6 & 10.4 \\
\hline Moisture Content & 100*(a-b) & 35.6 & 30.2 & 26.7 & 22.5 & 17.3 & 16.9 \\
\hline
\end{tabular}

Therefore, the Liquid limit at blow $25=26.5 \%$; Plastic limit $=17.1 \%$; Plasticity index $=8.5 \%$ 


\begin{tabular}{|ll|l|l|l|l|l|l|l|}
\hline \multicolumn{1}{c}{ Table 4: Liquid and Plastic Limits for Sample X } \\
\hline Test Type & Expression & \multicolumn{3}{c|}{ Liquid Limit } & \multicolumn{3}{c|}{ Plastic Limit } \\
\hline Number of Blows & & 10 & 19 & 28 & 39 & & \\
\hline Number of Container & & 1 & 12 & 2 & 18 & 22 & 36 \\
\hline Weight of soil + container & W2 & 40.5 & 39.4 & 38.7 & 38.3 & 34.3 & 34.8 \\
\hline Weight of dry soil container & W3 & 35.9 & 35.5 & 35.3 & 35.4 & 32.6 & 33.0 \\
\hline Weight of empty container & W1 & 23.0 & 23.0 & 23.0 & 23.0 & 23.0 & 23.0 \\
\hline Weight of moisture & W2-W3(a) & 4.6 & 3.9 & 3.4 & 2.9 & 1.7 & 1.80 \\
\hline Weight of dry soil & W3-W1(b) & 12.9 & 12.5 & 12.3 & 12.4 & 9.6 & 10.0 \\
\hline Moisture Content & $100 *(a-b)$ & 35.7 & 31.3 & 27.8 & 23.7 & 17.7 & 18.0 \\
\hline
\end{tabular}

Therefore, the Liquid limit at blow $25=28.2 \%$; Plastic limit $=17.9 \%$; Plasticity index $=10.3 \%$

Table 5: Result Summary for Muko, Jikwoyi and Apiwe Natural Lateritic soil material

\begin{tabular}{|c|c|c|c|}
\hline Test & \multicolumn{3}{|c|}{ Samples } \\
\hline Parameters & $\mathbf{X}$ & $\mathbf{Y}$ & $\mathbf{Z}$ \\
\hline Natural Moisture Content & $5.7 \%$ & $7.6 \%$ & $7.6 \%$ \\
\hline Specific Gravity & 2.40 & 2.49 & 2.02 \\
\hline Liquid Limits & $26 \%$ & $26.5 \%$ & $28.2 \%$ \\
\hline Plastic Limits & $16.6 \%$ & $17.1 \%$ & $17.9 \%$ \\
\hline Plasticity Index & $9.4 \%$ & $8.5 \%$ & $10.3 \%$ \\
\hline Percentage Passing 200 Micron Sieve & 43 & 37 & 37 \\
\hline FMWH Classification & $\mathrm{A}-3$ & $\mathrm{~A}-4$ & $\mathrm{~A}-5$ \\
\hline Maximum Dry Density & $1.86 \mathrm{Mg} / \mathrm{M}^{3}$ & $2.21 \mathrm{Mg} / \mathrm{M}^{3}$ & $1.81 \mathrm{Mg} / \mathrm{M}^{3}$ \\
\hline Optimum Moisture Content & $16.2 \%$ & $17.5 \%$ & $18.4 \%$ \\
\hline California Bearing Ratio & $50.8 \%$ & $36.9 \%$ & $33.1 \%$ \\
\hline
\end{tabular}

\subsection{Result Discussion}

The value of the samples $\mathrm{X}$ and $\mathrm{Y}$ Specific gravity are above 2.2 specified by (FGN, 1997) thereby were considered adequate while that of $\mathrm{Z}$ is below the specified value thereby requiring stabilization. The values of liquid limit (LL) and plasticity indices from samples $\mathrm{X}, \mathrm{Y}$ and $\mathrm{Z}$ ranges from 26.029.2 which meet with $(\mathrm{FGN}, 1997)$ standard for embankment, sub-base and base course. From the Figure 4 to Figure 6, the maximum dry density (MDD) and optimum moisture content
(OMC) of the samples ranges from $1810-2210 \mathrm{Kg} / \mathrm{m} 3$ and 16.2-18.4\% respectively. These values are considered good according specification (FGN, 1997). This implies that samples X can be recommended for base course as it satisfies the Nigeria standard specification for Road and Bridges though the soil needs to be improved with some admixture like Cement or Lime for better performance. On the order hand, the result from samples $\mathrm{Y}$ and $\mathrm{Z}$ are adequate only for sub grade, sub base and general fills, but not good as a base course material and can be recommended as such.

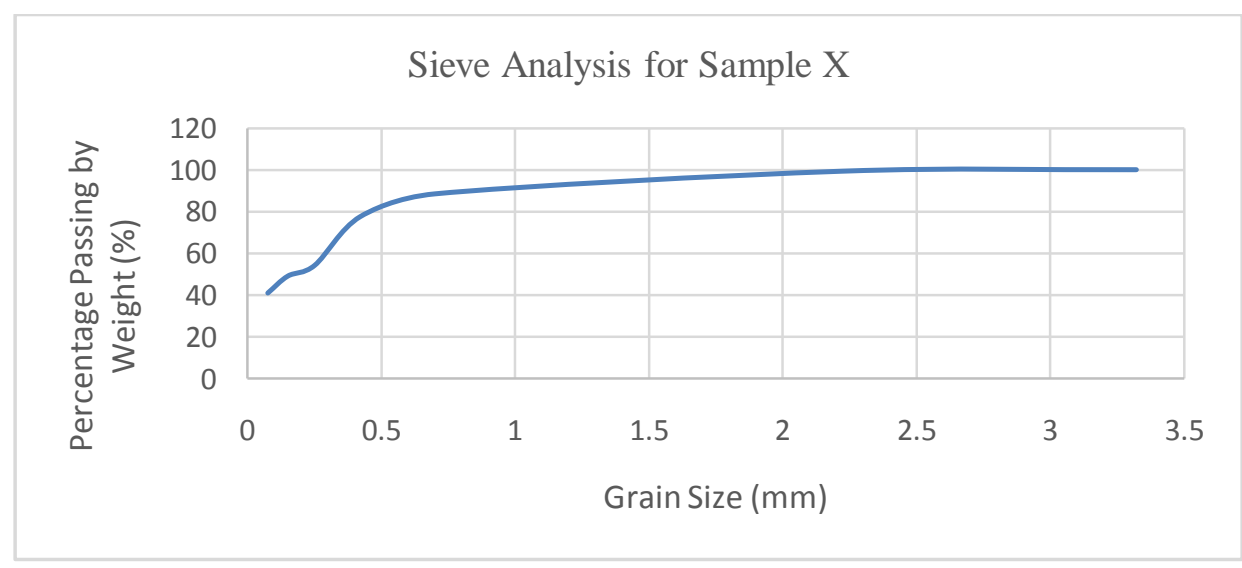

Figure 1: Graph of \% Passing and grain size for Sample $X$ 
Sieve Analysis for Sample Y

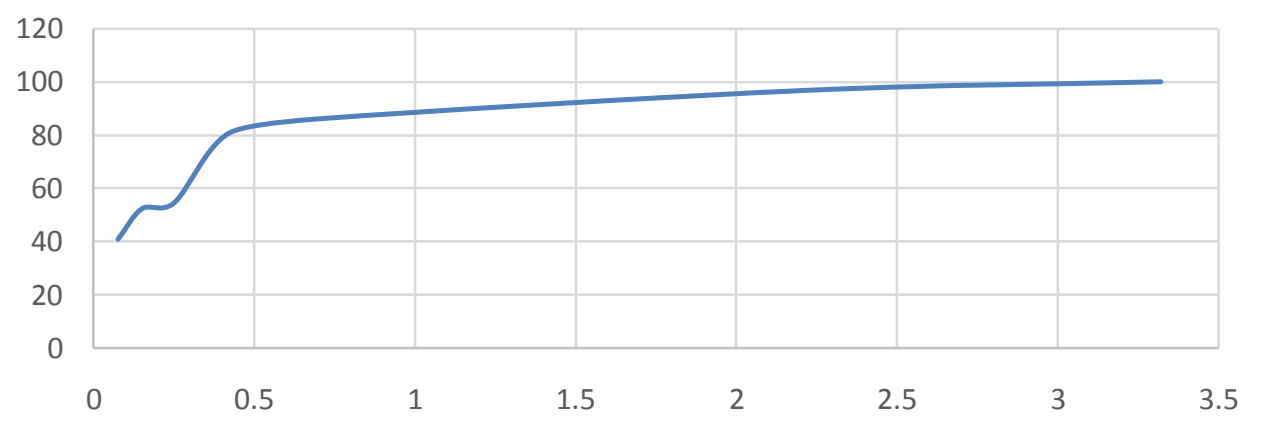

Figure 2: Graph of \% Passing and grain size for Sample Y

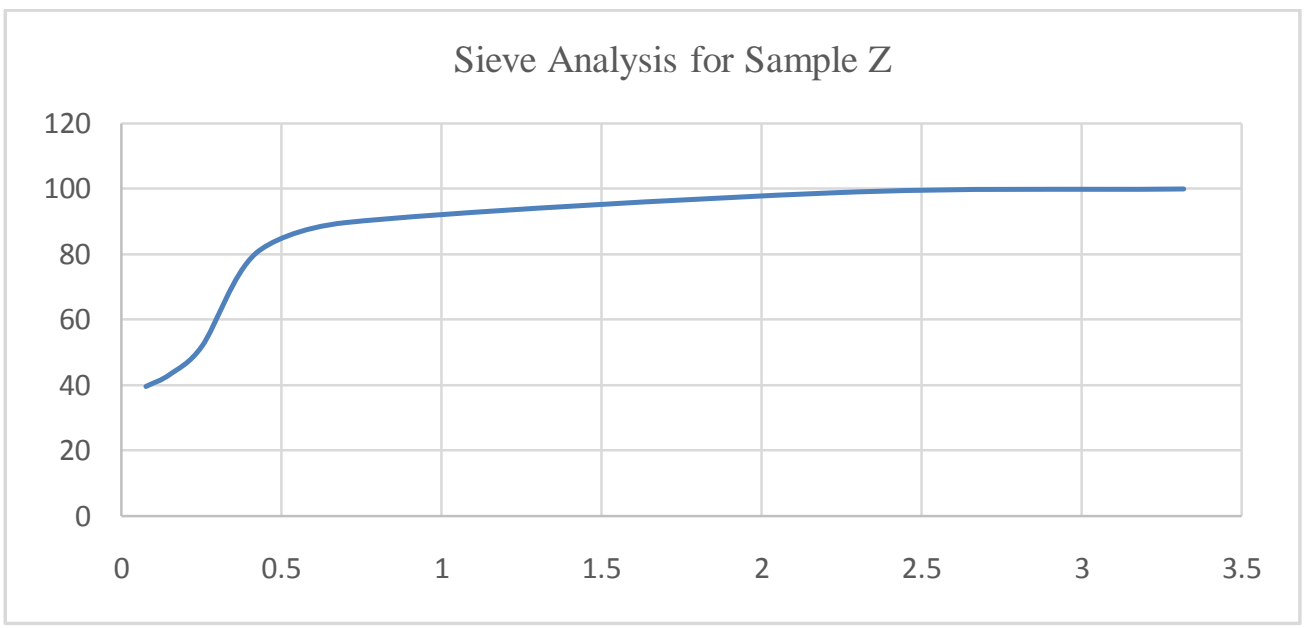

Figure 3: Graph of \% Passing and grain size for Sample Z

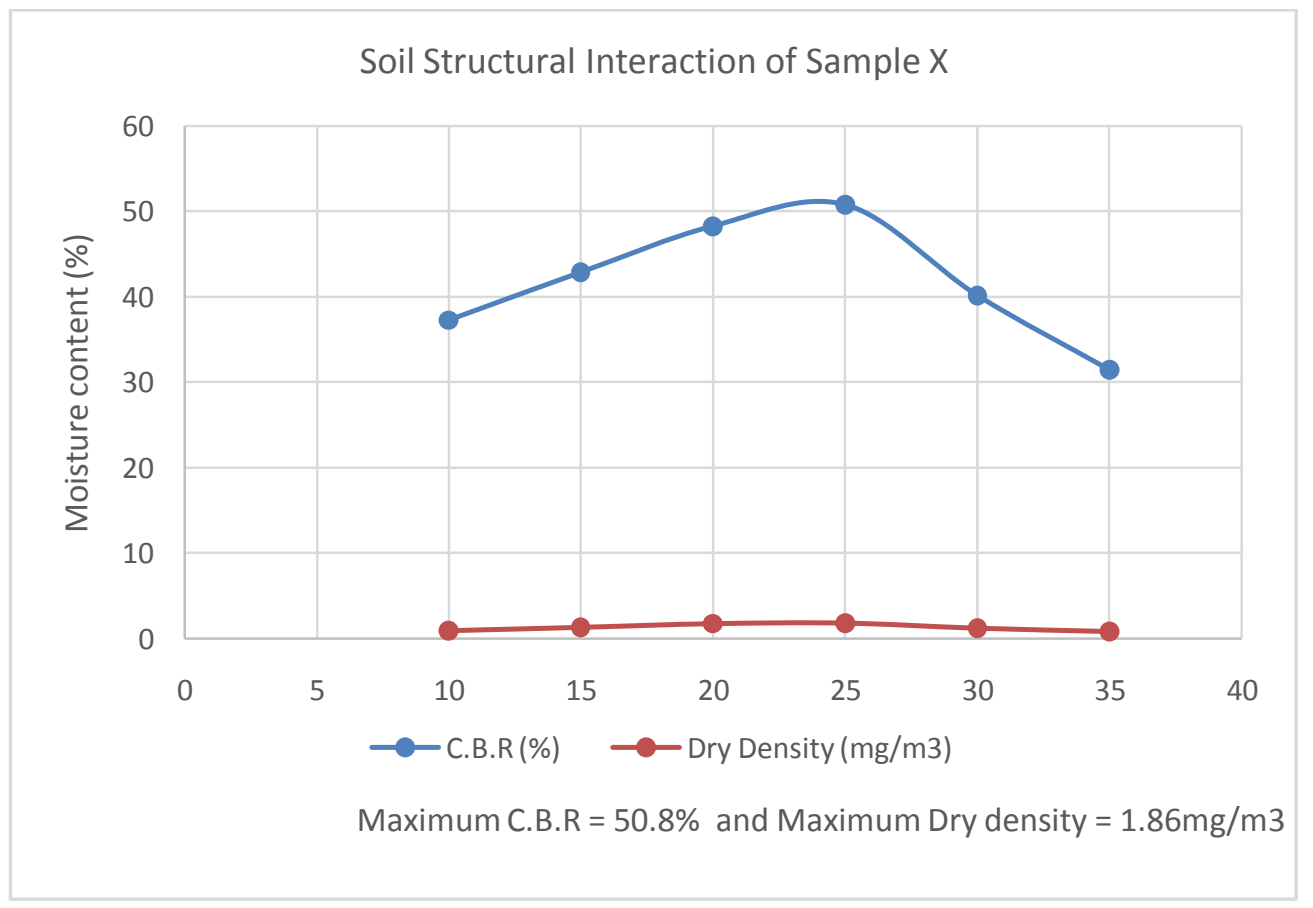

Figure 4: Graph of Optimum Moisture content (\%) versus CBR (\%) and M.D.D (mg/m $\mathrm{m}^{3}$ ) for Sample X 


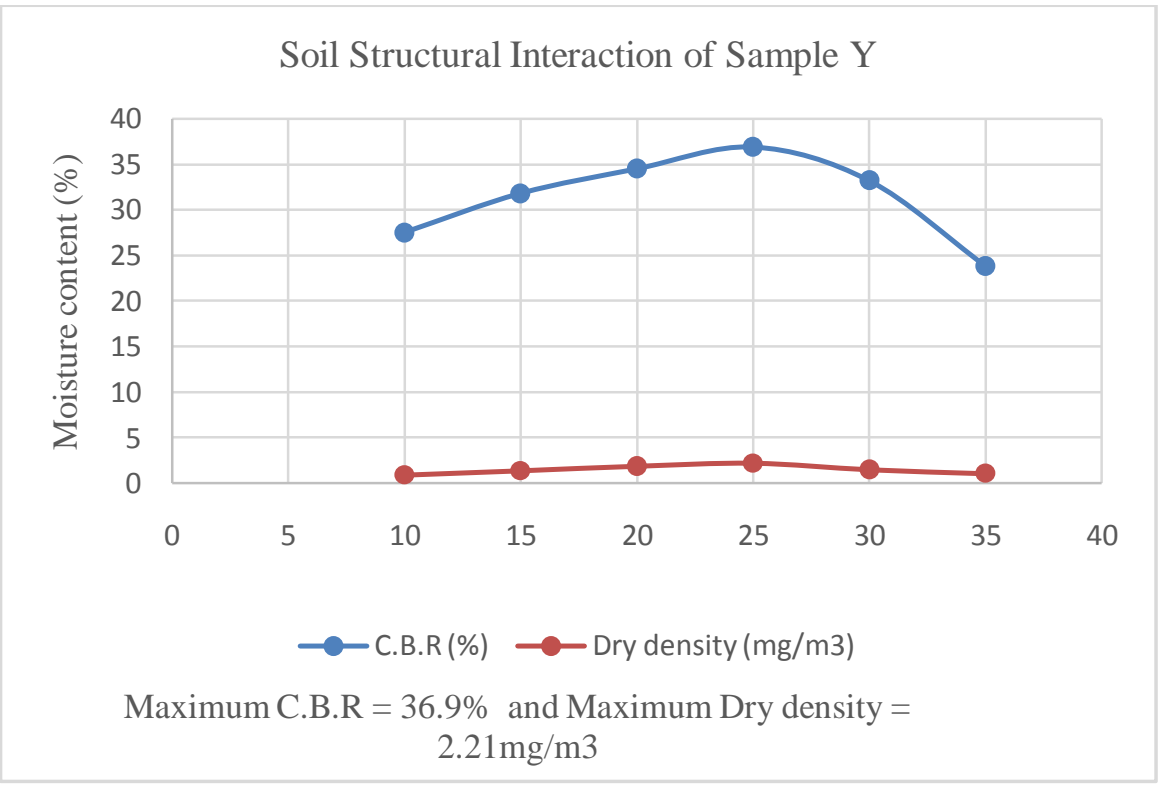

Figure 5: Graph of Optimum Moisture content (\%) versus CBR (\%) and M.D.D $\left(\mathrm{mg} / \mathrm{m}^{3}\right)$ for Sample Y

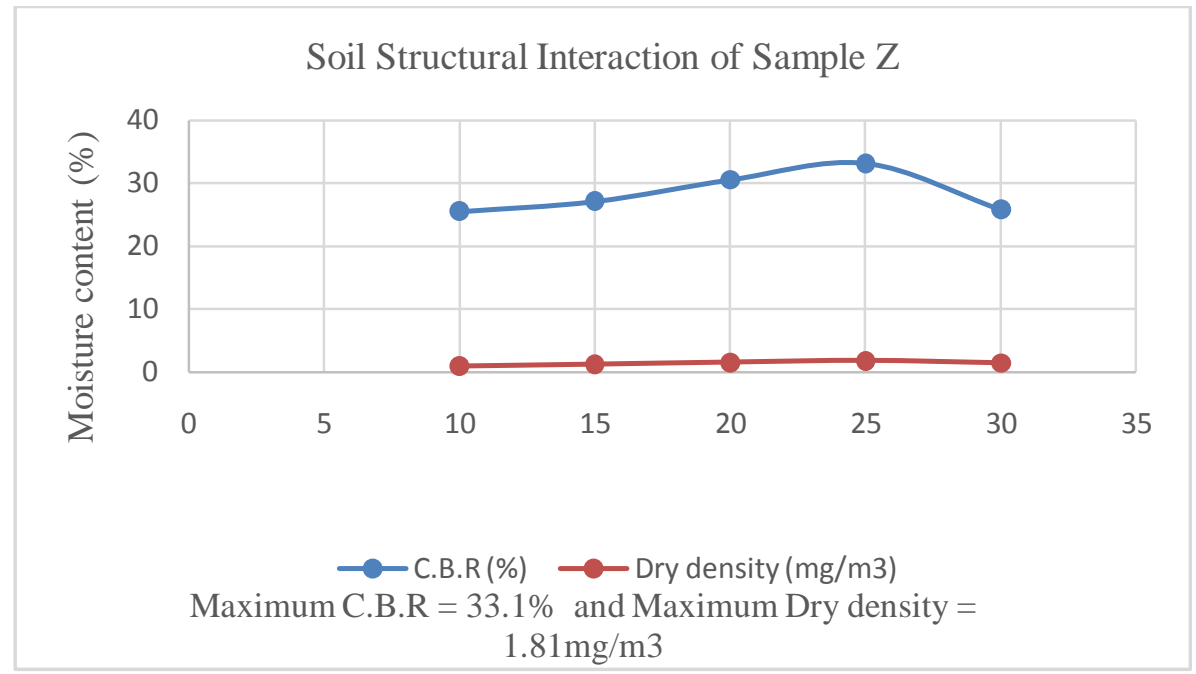

Figure 6: Graph of Optimum Moisture content (\%) versus CBR (\%) and M.D.D (mg/m $\left.\mathrm{m}^{3}\right)$ for Sample $\mathrm{Z}$

\section{CONCLUSION}

The research revealed that samples $\mathrm{X}, \mathrm{Y}$ and $\mathrm{Z}$ a generally suitable for subgrade subbase and backfill material using (FGN, 1997) as a yardstick. Having met up to standard in most of the Geotechnical test carried out. Soil stabilization is the alteration of soils to enhance their physical properties and can also be used to increase the shear strength of a soil. The findings of this research highlighted that the soil can be stabilized using lime and ordinary Portland cement (Onyeka, 2019). The soil sample $X$ that is treated with $10 \%$ ordinary Portland cement recommended as base course material for road construction. This mixture satisfies both the strength and durability requirements that were set by different agencies for base course materials. Meanwhile, the CBR test result showed that the sample $\mathrm{Y}$ soil when treated with $10 \%$ ordinary Portland cement can be used for sub-base construction.
Sample Z falls below the (FGN, 1997) standard in most of the soil test carried out and therefore not suitable as a road construction rather can be recommended for backfill material. Average specific gravity for the three samples is 2.33 the value which is above 2.2 specified by (FGN, 1997) shows that the soil structural material can be used in a combined form for the purpose of road construction etc.

\section{REFERENCES}

[1] AASHTO (1986). "Standard Specification for Transportation Materials and Methods of Sampling and Testing", 14th Edition. American Association of State Highway and Transportation Officials: Washington, D.C.

[2] Abiola. M. Dauda, Joseph O. Akinmusuru, Oluwaseun. A. Dauda, Taiwo O. Durotoye, and 
Kunle E. Ogundipe, Kehinde O. Oyesomi (2018). "Geotechnical Properties of Lateritic Soil Stabilized with Periwinkle Shells Powder".

[3] Aginam C. H, Nwakaire Chidozie, Nwajuaku A. I. (2014) "Engineering Properties of Lateritic Soils from Anambra Central Zone, Nigeria". International Journal of Soft Computing and Engineering, vol. 4, issue-6, pp. $1-7$.

[4] Akintorinwa, O. J., Ojo, J. S. and Olorunfemi, M. O. (2012). "Geo-electric Reserve Estimation of Laterite Deposits along a basement complex Underlain Oshogbo-Iwo Highway, Southwest Nigeria". Journal of Emerging Trends Engineering and Applied Sciences, vol. 3, issue-3, pp. $490-496$.

[5] Amadi A.N., Akande W. G., Okunlola I. A., Jimoh M.O., and Francis Deborah G. (2015). “Assessment of the Geotechnical Properties of Lateritic Soils in Minna, North Central Nigeria for Road design and Construction", American Journal of Mining and Metallurgy, vol. 3, issue-1, pp.15-20.

[6] Arinze Emmanuel Emeka and Ibe, Kingsley Emeka (2015). "Comparative Study of Geotechnical Properties of Abia State Lateritic Deposits", Journal of Mechanical and Civil Engineering, vol. 12, issue1 , pp. $77-84$.

[7] Avwenagha E. Oghenero, Arong T. Okey, Overare Brume, Okunuwadje S. E. and Osokpor Jerry (2014). "Classification and compaction characteristics of lateritic soils of Warri, Delta state, Nigeria". Advances in Applied Science Research, vol. 5, issue3.pp. $451-457$.

[8] Ehujuo, N. N., Okeke, O. C. and Akaolisa, C. C. Z. (2017). "Geotechnical Properties of Lateritic Soils Derived from Various Geologic Formations in Okigwe Area, Southeastern Nigeria”. FUTO Journal Series (FUTOJNLS), vol. 3, Issue-2, pp. 178 - 189.

[9] Enaworu E., Ugbe F. C., Rotimi O. J., Ameloko A. A.(2017). "Geochemistry and Geotechnical Analysis of Lateritic Soils in the Anambra Basin", EJGE, vol. 22, issue-11.

[10] Eze E. O., Adeyemi. G. O. and Fasanmade P. A. (2014). "Variability in Some Geotechnical Properties of Three Lateritic Sub-Base Soils Along Ibadan Oyo Road", Journal of Applied Geology and Geophysics, vol. 2, Issue-5, pp. $76-81$.

[11] Federal Ministry of Works and Housing (1997). "General Specification for Roads and Bridges, Federal Highway Department (FMWH), Lagos, Nigeria", Vol. II, 317.

[12] Habeeb A. Quadri, Olabambo A. Adeyemi, Oladipupo S. Olafusi (2012). "Investigation of the Geotechnical Engineering Properties of Laterite as a
Subgrade and Base Material for Road Constructions in Nigeria", Civil and Environmental Research, vol. 2 , issue-8.

[13] Layade Gideon Oluyinka, Ogunkoya Charles Olubunmi (2018). "Geotechnical properties of lateritic soil as subgrade and base material for road construction in Abeotuka, Southwest Nigeria", International Journal of Advanced Geosciences, vol. 6 , issue-1, pp. $78-82$.

[14] Ogbuagu, F. U and Okeke, C. A. U. (2019). "Geotechnical properties of lateritic soil from Nimo and Nteje areas of Anambra State, Southeastern Nigeria". 1st International Conference on Sustainable Infrastructural Development. IOP Conf. Series: Materials Science and Engineering, 640 (2019) 012078.

[15] Ola, S. A. (1978). "Geotechnical Properties and Behaviour of Some Stabilized Lateritic Soils". Quarterly Journal of Engineering Geology, vol. 11, pp. 145-160.

[16] Olaniyan O.S., Adisa O. A., Ayinde R.B., Olagbemiro B.O.(2019). "Geotechnical Properties of Lateritic Soil at Some Selected Portions acrossOld Ogbomoso-Ilorin Road", Journal of Sustainable Construction Engineering and Project Management, vol. 2 Issue-3, pp. 1 - 7.

[17] Onyeka, F. C. (2019). "Application of Industrial Waste (Saw-Dust Ash) in the Production of SelfCompacting Concrete", International Research Journal of Innovations in Engineering and Technology (IRJIET), vol 3, issue 11, pp. 1-9.

[18] Onyelowea, K. C and Agunwamba, J. C. (2012). "Geotechnical examination of the geophysical properties of Olokoro borrow site lateritic soil for road works", Nigerian Journal of Technology (NIJOTECH), vol. 31, issue-3, pp. $397-400$.

[19] Osim, Adebisi Ramota (2006). "Distribution of Engineering Properties of Soils used in Highway Construction in Nigeria", Msc thesis, Department of Civil Engineering Ahmadu Bello University, Zaria Nigeria, 2006.

[20] Prasad, T. K. and Parthasarathy, G.R. (2016). "Laterite and Laterization-A Geomorphological Review".

[21] Rahardjo, H., Aung, K.K., Leong, E.C., and Rezam, R. B. (2004). "Characteristics of Residual Soils in Singapore as Formed by Weathering", Journal of Engineering Geology, vol. 73, pp. 157-169.

[22] Tijani, Murtadha Adekilekun, Akinleye, Monsuru Tunde, Jaiyeoba and Kehinde Folake (2017). "Engineering Properties of Laterites Obtained in Ede, Southwestern Nigeria", International Journal of 
Engineering and Advanced Technology, vol. 7, Issue-

1 , pp. $160-162$.

\section{Citation of this Article:}

Onyeka, F. C., Osegbowa Douglas, "Soil Structural Analysis of Laterite Properties used as a Road Construction Material, Abuja as a Case Study" Published in International Research Journal of Innovations in Engineering and Technology - IRJIET, Volume 4, Issue 11, pp 35-42, November 2020. DOI of article https://doi.org/10.47001/IRJIET/2020.411005 